\title{
Navigating in a Hierarchy: How Middle Managers Adapt Macro Design
}

\author{
Marianne Livijn(1)
}

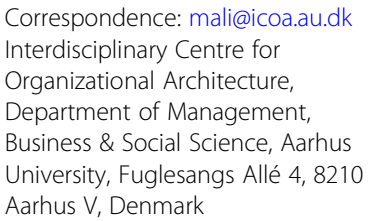

Correspondence: mali@icoa.au.dk Interdisciplinary Centre for Organizational Architecture, Department of Management, Business \& Social Science, Aarhus University, Fuglesangs Allé 4, 8210 Aarhus V, Denmark

\begin{abstract}
With the emergence of new organizational forms promoting de-layering, downscoping, and self-management, middle managers have been under attack in recent years. Organizational design has traditionally been concerned with how top management designs organizations, and little is known about the role of middle managers in organizational design. Based on a case study of a reorganization in a leading food production company, this paper contributes to existing research on organizational design by advancing the knowledge of the role of middle managers in organizational design. It contributes to an understanding of organizational design as an iterative process that require active involvement of middle managers in designing micro dimensions of a macro design. In doing so, I provide an extension of prior work, which mainly focuses on vertical interactions and middle managers' efforts to implement the intent of top management. I introduce a new middle manager role, designing, that relies on lateral rather than vertical coordination and interaction. I show how this role creates micro-level organizational elements needed to realize the intent behind top management's strategy and make the macro structural arrangements work. These findings elevate the importance of middle managers in new forms of organizing.
\end{abstract}

Keywords: Organizational design, Micro design, Macro design, Middle manager strategic influence, Reorganization

\section{Introduction}

Increasingly competitive and multifaceted business landscapes have led to heightened research interest in new organizational forms. The premise is that increasing environmental complexity requires greater organizational flexibility and therefore new forms of organizing (Puranam 2012; Van de Ven et al. 2013). These new forms of organizing are often associated with modulation, de-layering, decentralization, downscoping, and geographical distribution (Bernstein et al. 2016). While these developments may call for redundancy of middle managers (Cameron et al. 1991; Cascio 1993), recent research presents the opposite argument: "flatter" and more dynamic organizations elevate the role of middle managers as the strategic link that connects macro and micro levels in organizations (Balogun 2003; Balogun and Johnson 2004; Floyd and Lane 2000). Meanwhile, organizational design traditionally assumes that top management designs organizations (e.g., Donaldson 2001; Burton et al. 2002), and thus little is known about the role of middle managers in organizational design. Most research has focused on how organizational design influences middle manager morale, workload,

(c) The Author(s). 2019 Open Access This article is distributed under the terms of the Creative Commons Attribution 4.0 International License (http://creativecommons.org/licenses/by/4.0/), which permits unrestricted use, distribution, and reproduction in any medium, provided you give appropriate credit to the original author(s) and the source, provide a link to the Creative Commons license, and indicate if changes were made. 
and responsibilities (Thomas and Dunkerley 1999) and views middle managers as recipients of organizational design rather than playing an active role.

Primarily taking a macro approach, existing organizational design literature is often criticized for being too static to inform organizational design in modern organizations (Fjeldstad et al. 2012; Puranam 2018). The past decade has shown a growing research interest in micro approaches to organizational design that focuses on how designs develop further down in the organization (e.g., Puranam 2018; Nickerson and Zenger 2002; Liedtka 2014). While these emerging approaches provide valuable insight into organizational design in a more dynamic perspective, research is still at early stages and mostly conceptual, and does not specifically address the role of middle managers in organizational design. To develop better theories addressing new forms of organizing, the field of organizational design needs to study how designs are shaped at the micro level: ...useful theories of organization design are likely to emerge from knowledge (rather than assumptions) about how individuals interact in organizational contexts (Puranam 2012, p. 18).

Responding to similar critique that existing organizational design research face, strategy scholars have provided valuable insights and more dynamic theories of strategy by shifting focus from a macro to a micro perspective. For instance, Huy (2001, 2002), Floyd and Wooldridge (1997), and Balogun and Johnson (2004) have highlighted the crucial role that middle managers play in implementing strategies and ensuring continuous adaption to changing environments. In particular, the work of Floyd and Wooldridge $(1992,1997)$ has shown how middle managers are the strategic link between macro and micro levels by translating macro-level-derived strategies into micro-level actions. This paper analyzes how middle managers adapt a macro design by defining micro aspects of it. This leads to the overall research question for this paper: What is the role of middle managers in adapting a new macro design at a micro level?

Combining theoretical perspectives of organizational design and the strategic influence of middle managers allows for understanding the dynamic nature of adapting a new organizational design by focusing on the interaction between middle managers and the design. The use of the word "adapt" implies an adjustment of the design and thus an active position (the middle manager engages with the design), as opposed to "implement," which connotes a more passive approach.

The empirical foundation of this paper is a case study of a large reorganization in a European food production company. I examined the middle manager role in the reorganization, as opposed to the more commonly researched top management role in organizational design. I observed and interviewed managers at four different managerial levels and examined how these managers adapted a top-down reorganization in which top management outlined a new macro design with the aim of reducing costs by $25 \%$. The top management then left the overall reconfiguration to middle managers to make it fit to specific circumstances in the parts of the organization for which they were responsible. In this way, the middle managers were recipients of the reorganization as well as its implementers. They had to make the new design work but had little involvement in the initial redesign. While middle managers may have had an overall understanding of the new design at the outset of the reorganization, the findings show that the actual reorganization emerged through the actions in which managers adapted the new design. As they worked through what they perceived as misfits in the new 
design, middle managers built micro structures to compensate for weaknesses in the macro design.

The paper contributes to existing research on organizational design by bringing evidence based on a case study about the role of middle management in fine-turning a large reorganization. In doing so, I provide an extension of prior work, which mainly focuses on vertical interactions and middle managers' efforts to implement the intent of top management (e.g., Floyd and Lane 2000; Floyd and Wooldridge 1997). In the present study, I highlight the role that middle managers fulfill, namely designing micro dimensions of a macro design. I show organization design as an iterative process, which involves translating top management's intent into action at lower levels. I show that this process creates micro-level organizational elements needed to realize the intent behind top management's strategy and make the macro structural arrangements work.

The paper first outlines the theoretical framework of the study, followed by an explanation of the methodology. The analysis then follows in two parts. In the first part of the analysis, I account for misfits in the new design perceived by middle managers, and how they engaged with these misfits. These strategies for engaging with the misfits ended up defining micro dimensions of the new macro design and thus represented adaptions of the new design. In the second part of the analysis, I compare these findings to existing theory on the strategic influence of middle managers. Finally, the paper concludes with consideration of the research contributions and implications for practice.

\section{Theoretical framework}

Reorganizations are typically associated with changes in the organization's structure or configuration (Chandler 1962). As the reorganization studied in this case did not only involve structural change, but also new roles, IT systems, work processes, and reward systems, a broader frame for studying the reorganization was needed. The field of organizational design considers an organization a product of a number of contingencies, and thus structure is just one part of an organization (Burton et al. 2002). Therefore, this paper takes an organizational design perspective for studying the reorganization and defines organizational design as the continuous alignment of strategy, structure, processes, people, and rewards (Galbraith 1974). The basic premise behind the definition is that organizations are information processing entities (Galbraith 1974).

A core theme in organizational design is the notion of fit and misfit, as research has shown that misfit leads to decreased organizational performance (Burton et al. 2002; Donaldson 2001). Literature on fit typically distinguishes between internal and external fit. Internal fit refers to the alignment of organizational strategy, structure, and processes, whereas external fit refers to the alignment of the organization with its environment (Nissen 2014). The information processing view of organizational design considers misfit to be a lack of fit between information processing demand and capacity (Burton et al. 2011). Faced with misfit, an organization has two options: either it can reduce the need for processing information or it can increase its capacity for processing information (Galbraith 1974). This paper adopts the notion of fit and misfit, although the intention is not to qualify the fit between the new organizational design and external contingencies. Rather, the intention is to understand the middle manager role in a reorganization. 


\section{Macro and micro approaches to organizational design}

As this paper is interested in how middle managers adapt a new design developed by top management, it is important to consider both macro and micro dimensions of the design process. Within organizational design literature, however, there are divergent definitions of macro and micro approaches to organizational design. In this paper, macro design is defined as an organization's overall design (strategy, structure, processes, rewards, and people) designed by top management. Micro design refers to "local" adaption of the overall design undertaken by middle managers.

Most macro approaches to organizational design follow Chandler's (1962) iconic notion "form follows strategy" in which the goal is to achieve fit between organizational components, starting with strategy, leading to increased performance and internal well-being (Doty et al. 1993; Burton et al. 2002). Macro approaches comprise configuration theories (Meyer et al. 1993; Miles and Snow 1978; Nadler and Tushman 1999; Whittington and Pettigrew 2003) and complementarity theories (Milgrom and Roberts 1995; Donaldson 2001; Siggelkow 2001; Burton et al. 2011). These perspectives focus on an organization's ability to create and maintain fit through episodic sequences of static organization (re)design. Design is a top management discipline that focuses on top-down implementation and takes place isolated from the day-to-day activities of the organization (Van de Ven et al. 2013). While macro approaches have been essential for building a scientific field of organizational design, they are often criticized for overlooking micro-level dynamics, and are too static to meet the demands of modern organizations (Nissen 2014; Greenwood and Miller 2010; Puranam 2012).

Examples of micro approaches to organizational design include complexity theories (e.g., Nickerson and Zenger 2002; Weick 2004; Martin and Eisenhardt 2010) and creativity theories (Van Aken 2005; Avital and Te'eni 2009; Liedtka 2014) and challenge the relatively static representation of organization design and fit in macro approaches. These theories are based on a more dynamic view of organizational adaption and evolution, and consider design a continuous activity. Following this logic, organizational design is a routine activity not only performed by top management but involving the whole organization (Nissen 2014). Instead of thinking of organizational design as a stable and final "product," advocates of this micro approach are interested in the process of design, thereby shifting focus from design to designing (Weick 2004; Boland et al. 2008; Liedtka 2014). This leads to a more dynamic concept of fit, since the organization is designed to be and remain in flux. Fit is not considered an end-state but a continuous management focus (Nissen 2014). While these new and more dynamic perspectives on organizational design may be better suited to modern organizations, they are often criticized for overlooking the overall strategic focus and rely too much on organizational members to "work their magic" without instructions (Van de Ven et al. 2013; Bernstein et al. 2016).

As a way of balancing macro and micro approaches to organizational design, Gulati and Puranam (2009) introduce compensatory fit, in which they show the possible benefits of inconsistencies between formal and informal organizations during reorganization. Under certain conditions, the informal organization can compensate for the formal organization, making ambidextrous organization possible. Compensatory fit thus challenges the idea of internal alignment that seems implicit in existing organization design literature. 
Although research within organizational design has taken important steps toward developing more dynamic theories of organizing, research is still at early stage and is mostly conceptual. Recent calls have been made for more research on micro approaches to organizational design based on knowledge on how people interact in organizations (Puranam 2012, 2018; Van de Ven et al. 2013; Greenwood and Miller 2010). It is the aim of this paper to address these calls by examining how middle managers adapt macro design. In order to fully appreciate this question, it is important to understand the role and actions of middle managers.

\section{The strategic influence of middle managers}

Middle management comprises managers who both lead others and are led by others (Floyd and Wooldridge 1997). The trend toward organizational downsizing, reengineering, and larger degree of self-management in recent years has led to a reduction of middle managers in many organizations (Balogun 2003). As a result, the role of middle managers has been under attack, some arguing that middle managers are redundant in modern organizations (Cameron et al. 1991; Scarbrough and Burrell 1996). However, recent research suggests that middle managers play a crucial strategic role in modern organizations (e.g., Huy 2001, 2002; Floyd and Wooldridge 1997; Balogun and Johnson 2004). For instance, Balogun and Johnson (2004) highlighted the crucial role that middle managers played in facilitating sense making and accomplishing an organizational restructuring. Moreover, Floyd and Lane (2000) found that middle management activity is central to organizational renewal.

A central theme in existing literature on middle managers is managerial discretion, i.e., the extent to which the middle manager is able to influence his area of responsibility and make decisions without the involvement of his superior (Huy 2002). Ahearne et al. (2014) showed how middle managers' strategy involvement follows an inverted U shape, reflecting a flexibility-control paradox. These authors show that the benefits of middle managers' strategy involvement persisted only up to a certain threshold. After this, the benefits were outweighed by problems associated with lack of strategic control. Relating this to organizational design, these findings necessitate a delicate balance between macro and micro approaches, as organizations need to design a coherent organization, while at the same time allowing for micro-level adjustments to local markets and circumstances (Van de Ven et al. 2013).

Examining the role of middle managers in organizational strategy, Floyd and Wooldridge (1997) identified two upward and two downward forms of middle management influence activity and showed how they contributed in implementing strategies. Middle management's upward influence activities have the potential to influence the organization's strategic course by providing top management with interpretation of emerging issues by proposing new initiatives. Upward influence includes a synthesizing role in which managers interpret ambiguous data and change the strategic agenda (Dutton and Jackson 1987) and a championing role where managers advocate new ideas and reshape the strategic thinking of top management (Floyd and Wooldridge 1997). The downward influence of middle managers relates to their role as change agents and comprises a facilitating role that stimulates development in others and promotes learning, and an implementing role where managers engage in an ongoing set of interventions that create organizational 
action in line with overall strategies (Sayles 1993). The implication is that in each role, middle managers have the potential to affect the organization's strategy processes by challenging the current mindset (Floyd and Wooldridge 1997).

\section{Case description}

As the case company wishes to be anonymous, I will refer to the case company as FOOD. Employing approximately 30,000 employees, FOOD is one of the largest food production companies in Europe, with an annual revenue of around 40 billion euro.

FOOD struggled to deliver sufficient return to owners due to increased competition and environmental uncertainty. To address high operating costs due to past mergers, combined with new market conditions, FOOD launched a new strategy and a company-wide reorganization. The new strategy focused on efficiency and streamlined a range of core processes to generate synergy and transparency across the organization. At the same time, FOOD continued to want newly acquired units to operate largely independently.

To understand the middle manager role in this process, I use in-depth data from FOOD's finance function, as the reorganization involved a complete redesign of FOOD's finance function. Before the reorganization, the company had a divisional structure, with each division having its own finance function. With the new strategy, finance was restructured into one corporate function serving the global organization. As a consequence, staff was reduced by $25 \%$ and a large number of employees and managers got new roles. The new finance organization was divided into four sub-functions: process optimization, performance management, business partnering and controlling, as can be seen in Fig. 1. Playing a central role in the daily operations in the company, the reorganization in finance was rolled out at the same time as running "business as usual."

When data collection started, the company was 6 months into the reorganization process and 12 months after the first announcement of the reorganization.

FOOD has a proud tradition for its annual strategy processes in which the company's overall strategic goals are cascaded through a goal hierarchy, highlighting each department's contribution and take on the strategy. Based on these cascaded goals, each part

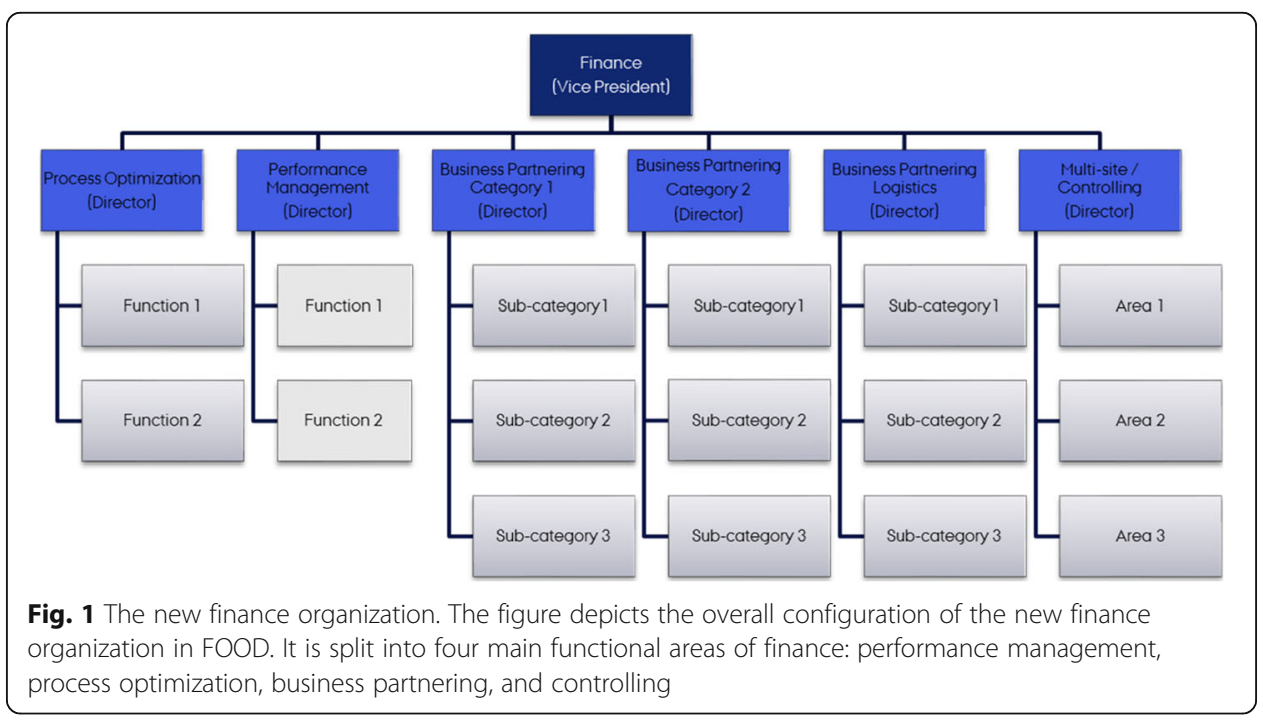


of the business develops a 12-month business plan intended to bring the strategy into action. It was through the work with the strategy implementation that middle managers experienced the need to adapt the macro design at the micro level. The executive management in finance thought that they had developed a solid new organizational design and had not considered that middle managers should be a part of the design process. Therefore, the incentives in the new organizational design focused on how well managers contributed toward the fulfillment of the must-wins in the new strategy (e.g., "strong finance fundamentals" and "number of standardized finance processes") and not their contribution to building on the design. The strategy must-wins are illustrated in Appendix 1.

The company has a strong performance culture where the top management expect people to deliver their targets no matter what it takes. The following illustrate the culture as expressed by different managerial levels:

I am confident that people will whip themselves, so they do not need me to do that. We do that when we set some clear and hard goals together. People that work here know that they have to deliver, otherwise they're out. So I am mostly focused on supporting the individual to be able to deliver. (Vice President)

We have been through several rounds of layoffs, so we have gotten rid of low performers or people with bad attitude. I guess we all feel pride in the company and want us to succeed. We have a long and proud history. So you also have to pull yourself together in times like this when things are a bit turbulent. (Director, Business Partnering)

The top management expect a lot from us and expect us to react immediately when issues occur. So you kind of have to be on top of your game all the time. Stress has been a big issue in my team, so we have been understaffed for some time. Then you could imagine that they would adjust our targets or give us some slack. But it has really been the other way around. They have pushed even harder because we were falling behind. (Manager, Performance Management)

While acknowledging that the reorganization of FOOD finance was a part of a larger reorganization, for the purpose of this paper, the executive management team in FOOD finance (vice president and directors) represent the macro design, and middle managers (senior managers and managers) represent the micro design. This way, the case study does not deal with the overall reorganization of FOOD. The unit of analysis is thus FOOD's finance function. The executive management, comprising the vice president of finance and six directors that each are responsible for a functional unit within finance, make all strategic decisions for the finance area. They operate in close cooperation and have weekly management meetings. The management system also consists of nine senior managers and seven managers that manage the employees within finance. The extended management team thus comprises 23 managers at different levels. The extended management team meets twice a year to discuss the finance strategy and business plan.

\section{Method}

As existing literature contains limited knowledge on how middle managers adapt macro design, a qualitative research approach was chosen for this study. Qualitative 
approaches are particularly relevant when the purpose is to explore a phenomenon in depth, i.e., to further the understanding of a particular phenomenon and develop explanations (Yin 2014; Eisenhardt 1989). A single case was chosen, as it allows for greater detail and nuances on the phenomenon being studied (Yin 2014), which was necessary for fully understanding the reorganization from a middle manager point of view. To ensure in-depth understanding, the case study was based on an embedded design (Eisenhardt 1989) and examined four different management levels in the case.

\section{Data collection}

The study involved multiple qualitative data sources (observations, interviews, and company documents), summarized in Table 1.

First, following preliminary interviews, I engaged in observations of meetings in the management team to understand how the reorganization was unfolding, what kind of issues were salient, and how the management was planning to move forward. The meetings ranged from 3 to 22 participants and lasted between $30 \mathrm{~min}$ and $5 \mathrm{~h}$. Detailed field notes were taken within $24 \mathrm{~h}$ of leaving the field. The notes included observations of the participants' actions and expressions as well as observed patterns of interaction between participants. Second, I conducted 15 semi-structured interviews with all 4 management levels (vice president, director, senior manager, and manager) within the new finance function. The interviews took place from February to March 2017. Each interview lasted 60-90 min and was audio recorded and transcribed. The respondents were selected in close cooperation with FOOD's HR department, based on the theoretically diverse principle (Yin 2014). The goal was to get at least two informants as representatives of each management level. The interview guide (Appendix 2) included questions about each respondent's role, perceptions of new design (opportunities and challenges), learnings from the reorganization so far, and how she or he had approached the reorganization within the area of responsibility and was planning to move forward. Company data primarily included strategy documents, meeting memos, and role charters for some of the new roles, as highlighted in Table 1.

\section{Analytic approach}

The analysis of the data was based on established techniques to move from raw data to theoretical insights, iterating between data collection, analysis, and existing literature (Langley 1999; Gioia et al. 2013; Eisenhardt et al. 2016; Smith and Besharov 2017).

Table 1 Overview of data sources

\begin{tabular}{llc}
\hline Source & Elaboration & Number \\
\hline Interviews with & Vice president & 1 \\
managers & Director & 6 \\
& Senior managers & 5 \\
& Managers & 3 \\
Observations & Meetings in executive management team in the finance function (vice president, & 15 (72 h) \\
& directors, and middle managers) & 38 \\
Company & Strategy documents, role charters, memos & \\
\hline
\end{tabular}


Though this process was not linear, it contained three main steps, as highlighted in Table 2.

\section{Develop a thick case description}

First, I developed a rich case description to integrate the different data obtained (Eisenhardt et al. 2016). In this processes, I mapped the different events (e.g., announcement of new organization, kick-off meetings, quarterly status meetings, informal meetings between middle managers) using visual mapping in order to create an overview of the reorganization process (Langley 1999). I regularly met with the company's HR department to share my interpretations and reflections to increase the reliability and comprehensiveness of my analysis (Smith and Besharov 2017).

\section{Code raw data and develop main constructs}

In the second stage of the analysis, I returned to the raw data to unpack the reorganization. In this process, I used prescribed techniques (Gioia et al. 2013; Langley 1999) to move from the raw data via conceptual categories to aggregated theoretical dimensions. This was an iterative process where I read the data several times and moved fluidly between the raw data and more abstract conceptual categories. I coded quotes and phrases from the raw data to derive at first-order codes. The initial coding amounted to around 50 codes, which were then aggregated into empirical categories, such as "reorganization process," "the new design," and "impact of new organization." Appendix 3 summarizes the different levels of codes. The identification of the empirical categories, combined with my experiences from the observations, helped me identify that some tensions existed within each category. For instance, in the category "the new design," the respondents were talking about very different organizations (e.g., "This is a simple functional organization," "it's a full-blown matrix," "there are a lot of

Table 2 Analytic approach (cf., Smith and Besharov 2017)

\begin{tabular}{|c|c|}
\hline Analytical activities & Generated output \\
\hline \multicolumn{2}{|l|}{ 1: Develop a thick case description } \\
\hline $\begin{array}{l}\text { - Organize and integrate the different data sources } \\
\text { - Use visual mapping } \\
\text { - Share interpretations with co-learners (HR) at } \\
\text { "learning meetings" to increase reliability } \\
\text { - Write thick descriptions generating an overview of } \\
\text { the design process }\end{array}$ & $\begin{array}{l}\text { - Visual map of the empirical context } \\
\text { - Visual representation of the new organization } \\
\text { - Initial key observation that informed subsequent } \\
\text { data analysis (middle manager role) } \\
\text { - Empirical thick case description }\end{array}$ \\
\hline \multicolumn{2}{|l|}{ 2: Code raw data to develop main constructs } \\
\hline $\begin{array}{l}\text { - Code raw data to understand the reorganization } \\
\text { - Merge empirical codes into empirical categories } \\
\text { - Thematic analysis to understand different } \\
\text { perceptions of new design } \\
\text { - Iterate between data and literature to develop } \\
\text { more abstract conceptual categories ad aggregated } \\
\text { theoretical dimensions } \\
\text { - Share interpretations with co-learners (HR) at } \\
\text { "learning meetings" to increase reliability }\end{array}$ & $\begin{array}{l}\text { - Visual representation of the new organization as } \\
\text { perceived by different managerial levels } \\
\text { - Data structure including empirical categories merged } \\
\text { into six conceptual themes and two aggregated } \\
\text { theoretical dimensions }\end{array}$ \\
\hline \multicolumn{2}{|l|}{ 3: Integrate data and literature } \\
\hline $\begin{array}{l}\text { - Explore the relationship between empirical } \\
\text { findings and existing literature }\end{array}$ & $\begin{array}{l}\text { - Extension of Floyd and Wooldridge's (1997) findings } \\
\text { on middle managers' strategic influence by adding a } \\
\text { new role (designing) }\end{array}$ \\
\hline
\end{tabular}


gray areas," "clear roles and responsibilities"). The category "the new design" became the primary focus in the first part of the analysis. I went back to the data in order to understand what kind of organization the respondents were talking about. This process was based on thematic coding (Braun and Clarke 2006). The five building blocks in Galbraith's (1974) five-star model (strategy, structure, processes, people, and rewards) were used as conceptual reference and thus constituted conceptual themes. This process illustrated considerably different perceptions of the new design among the executive management team (vice president and directors) and middle managers (senior managers and managers), as illustrated in Appendix 1. I then made a visual representation of how the design was perceived by executive management (Fig. 1) and middle management (Fig. 2). This process raised questions about how the different perceptions affected middle managers' work with implementing the new design.

Literature on design misfits (e.g., Galbraith 2014; Burton et al. 2002) emerged as particularly helpful to understand the implications of the different perceptions. Through this literature, it was possible to identify a number of perceived misfits in the new design (Table 3) that imposed challenges for middle managers when attempting to implement the new design in the daily work. "Misfit" (theoretical dimension) in the analysis referred to middle managers' perceived contradiction between two or more elements in the design and the reality in which it had to be implemented.

I then observed a number of activities and design elements that were not part of the new design in the initial case description (e.g., "We had difficulties with making people perform in the business partner role... we came up with this idea of starting a business partner community," "We have put people together in what we call excellence teams. We match controllers and business partners and let them sort out who is doing what"). I termed these "new initiatives." These new initiatives were started by middle managers and expressed middle managers doing something with the design. I used the conceptual theme "adapting design." I then went back to the analysis of the new design based on Galbraith's star model (1974) to see if there was any connection between the perceived misfits and middle managers' adaptions of the design. The iteration between data, categories, and theoretical terms revealed how the perceived misfits triggered middle

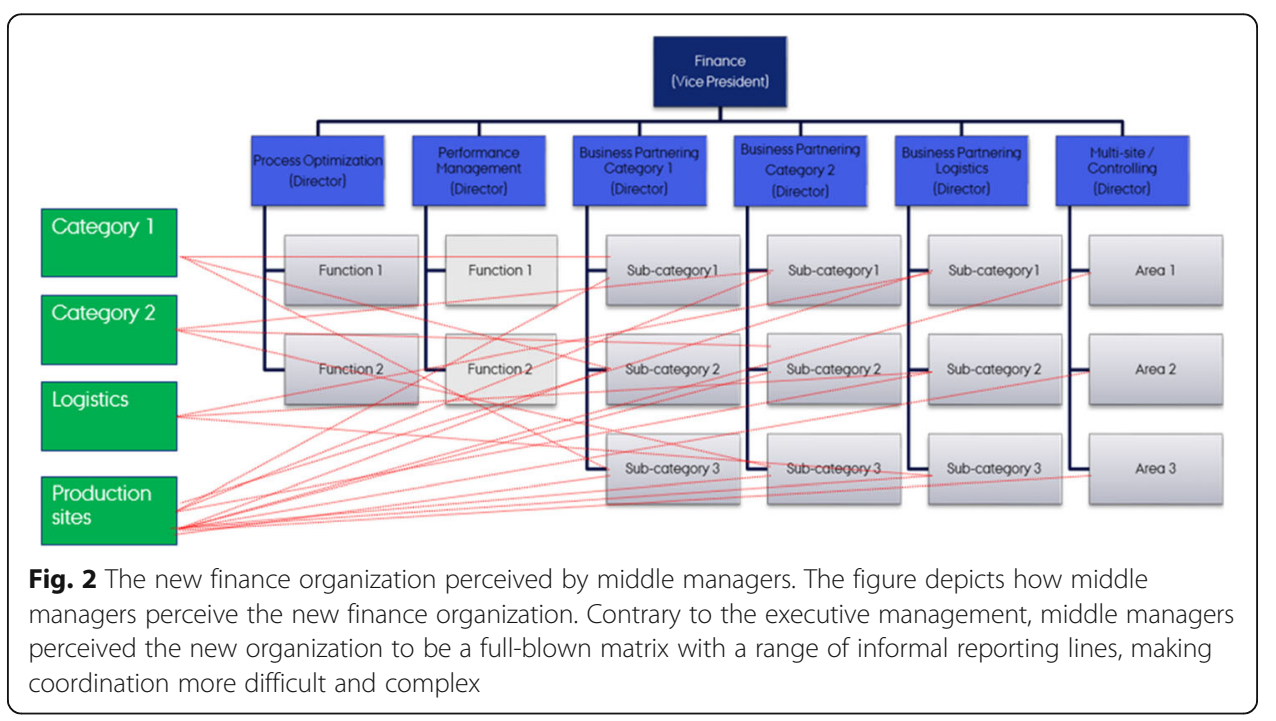


Table 3 Overview of middle managers' perceived misfits and strategies for engaging with the

\begin{tabular}{|c|c|c|}
\hline $\begin{array}{l}\text { Type of } \\
\text { misfit }\end{array}$ & Description & $\begin{array}{l}\text { Strategies for } \\
\text { engaging with the } \\
\text { misfit }\end{array}$ \\
\hline $\begin{array}{l}\text { Structure- } \\
\text { process }\end{array}$ & $\begin{array}{l}\text { New business partner role, but insufficient coordination mechanisms to } \\
\text { bring the role to life } \\
\text { Unclear interfaces between new business partner and controller }\end{array}$ & $\begin{array}{l}\text { Business partner } \\
\text { community } \\
\text { Excellence teams }\end{array}$ \\
\hline $\begin{array}{l}\text { Structure- } \\
\text { people }\end{array}$ & $\begin{array}{l}\text { Perceptions of the new structure as a matrix. No need for specialized } \\
\text { finance people, but people who can work the matrix }\end{array}$ & $\begin{array}{l}\text { "Buddy" arrangement } \\
\text { Safe haven } \\
\text { Sharing best practice }\end{array}$ \\
\hline $\begin{array}{l}\text { Strategy- } \\
\text { process }\end{array}$ & $\begin{array}{l}\text { Delayed SAP implementation and difficulty in using the system at } \\
\text { production sites }\end{array}$ & SAP service check \\
\hline $\begin{array}{l}\text { Structure- } \\
\text { rewards }\end{array}$ & $\begin{array}{l}\text { Perceptions of the new structure as a matrix. Rewards given based solely } \\
\text { on contribution to function }\end{array}$ & None observed \\
\hline
\end{tabular}

managers' adaptions, i.e., when the new design failed to respond to organizational reality. I then termed middle managers' adaptions of the new design "strategies for engaging with the misfit." Table 3 pairs the misfits perceived by middle managers and the corresponding strategies for engaging with each misfit.

\section{Integrate data and literature}

In the final part of the analysis, I examined the relationships between the conceptual categories and the aggregated theoretical dimensions using existing literature. First, inspired by the two key observations-the perceived misfits in the new design and middle managers as a central player in adapting the design and making it work-I engaged in reading on middle manager strategic role in strategy implementation and reorganizations. As most research on the middle manager role focuses on strategic influence and role, it seemed compatible with the "strategies for engaging with the misfit," as they focus on how the middle manager adapts the design and thus influences the design process. I found the work of Floyd and Wooldridge (1997) particularly insightful. I compared the six strategies for engaging with the misfit with the middle manager roles in Floyd and Wooldridge's (1997) framework. As Table 4 shows, I found support for two roles identified in the literature: facilitating ("sharing best practice," "buddy arrangement") and implementing roles ("safe haven," "SAP service check"). However, the comparison did not help me label the final two strategies: "business partner community" and "excellence teams." Looking through data, these strategies comprised activities that relied on lateral rather than vertical coordination as suggested by Floyd and Wooldridge (1997). Furthermore, the strategies did not just focus on translating strategy into action. Rather, the middle managers developed microstructures to enhance lateral coordination and collaboration needed to realize the new organization. This way, middle managers were not just implementing the design, but building on it. Therefore, I labeled these strategies designing. Table 4 illustrates the relationship between different strategies identified and existing research.

\section{Findings}

Figure 2 depicts the new finance organization as perceived by middle managers. This organization is in sharp contrast to Fig. 1, which illustrates the organization designed 
Table 4 Middle manager role in adapting macro design. Extended from Floyd and Wooldridge (1997)

\begin{tabular}{|c|c|c|c|}
\hline $\begin{array}{l}\text { Middle manager strategic } \\
\text { influence }\end{array}$ & $\begin{array}{l}\text { Direction in } \\
\text { hierarchy }\end{array}$ & Behaviors & $\begin{array}{l}\text { Strategies adopted in } \\
\text { case study }\end{array}$ \\
\hline Championing & Upward & $\begin{array}{l}\text { Present alternatives to top } \\
\text { management }\end{array}$ & \\
\hline Synthesizing & Upward & $\begin{array}{l}\text { Categorize issues and sell to top } \\
\text { management }\end{array}$ & \\
\hline Facilitating & Downward & $\begin{array}{l}\text { Share information and facilitate } \\
\text { learning }\end{array}$ & $\begin{array}{l}\text { Sharing best practice } \\
\text { "Buddy" arrangement }\end{array}$ \\
\hline Implementing & Downward & $\begin{array}{l}\text { Revise and adjust, motivate, inspire, } \\
\text { coach }\end{array}$ & $\begin{array}{l}\text { Safe haven } \\
\text { SAP service check }\end{array}$ \\
\hline Designing & Across & $\begin{array}{l}\text { Build collaboration and coordination } \\
\text { across hierarchy }\end{array}$ & $\begin{array}{l}\text { Excellence teams } \\
\text { Business partner } \\
\text { community }\end{array}$ \\
\hline
\end{tabular}

by the executive management. What to the executive management seemed like a functional structure was by middle managers experienced as a full-blown matrix with numerous "dotted lines" between the different finance functions, the line of business, and production sites, making coordination much more complex.

The analysis of the empirical data revealed that middle managers' adaption of the new design was related to perceived misfits between design components. The most significant of these are elaborated below, followed by an analysis of the strategies that the middle managers applied for engaging with the misfit and thus adapting the design. Table 3 outlines the complete list of perceived misfits that emerged from the analysis of the data. As a result of the perceived misfits, executive management and middle management were disconnected early in the reorganization, and thus little vertical coordination took place. The final part of this section accounts for the middle managers' strategic influence through their adaption of the new design.

\section{Perceived misfits}

\section{Structure-process misfit}

One of the major changes in the new organization was the creation of two new roles: finance business partner and controller. Before, each production site had a local finance manager. With the reorganization, all local finance managers got new roles. Five administrative centers were established (multi-sites) that served all production sites within their area. Primarily employing controllers, the role of multi-sites was to support production sites in accounting and bookkeeping, and to calculate key numbers for the finance business partners. Depending on production site sizes, the finance business partners serviced three to seven sites, and their role was to advice local management on strategic aspects related to finance and oversee performance across the sites for which they were responsible. While the interviewees reported that the spilt between business partner and controller was logic in theory, reality showed to be more complex:

I think that the main challenge at the moment is defining roles and the interactions between especially the business partner group and the controllers. The executive management have almost left us with a blank paper for these functions, and at the moment there is a lot of disagreement about who is in charge of what. (Senior Manager, Business Partnering) 
We are struggling to make people perform and deliver in the new roles. Particularly cooperation between our new business partners and controllers is difficult... I think a lot of it has to do with that people used to have very different roles and I am not sure whether they entirely understand the new work flow that we are trying to create. (Senior Manager, Performance Management)

I feel like the business partners are doing what they want and then we have to clean up. I mean...the sites have to get their numbers and stuff, so things have to get done. But often we get surprised by how little the business partners have done before they move on to the next. (Senior Manager, Controlling)

As can be inferred from the above, the introduction of the new roles led to perceived misfits at two levels. First, the respondents were reporting that the unclear role definitions led to divergent perceptions of the daily task division, and secondly there was a lack of coordination mechanisms to bind the two new roles together. As a way of clarifying the new roles and supporting coordination, the executive management developed a service-level agreement (SLA) that served as a contract between the production sites and the finance function, outlining which financial services the sites could expect. The SLA was also to specify the new roles, controller and business partner, and how the production sites could use them. However, it turned out that the middle managers did not find the SLA useful:

I guess the mild version is that the SLA is a work in progress. It is just one of those things where you think you can account for everything in a formal document, and then reality turns out to be something else. I think it is something that multi-site use, but we don't really use it. I prefer to talk to people. (Senior Manager, Business Partnering)

I like the SLA, and I think the new version is much better. But it is just really hard to live out in daily work. We constantly have examples of people not doing what is in the SLA. Or they do all kinds of stuff that goes way beyond what they have to do according to the SLA. It is really frustrating. I mean, how difficult can it be to read a document. So we have to make sure that everybody uses it. (Manager, Business Partnering)

As the above illustrate, the managers who worked closely with the production sites did not find the SLA useful, leaving a perceived misfit regarding how the new roles should be played out.

Strategies for engaging with the misfit Working across the lines: excellence teams Being frustrated that tasks either did not get solved or got solved twice, managers from controlling and business partnering hosted a number of meetings where all employees from business partnering and controlling were invited to discuss their roles and interfaces. Managers from controlling and business partnering explained: 
Basically the role charters tell us that controllers work with numbers in detail and the business partner is more overall. It is very difficult for our employees to understand what that means in practice. There are a lot of gray areas, and we try to discuss these together to come up with common solutions. (Manager, Controlling)

Sometimes my people feel that business partners do the fancy stuff and we have to be their assistants. That is really not the intention... So putting people in the same room and making them talk together and helping them realize how much they are dependent on each other...yeah, that has helped a lot. (Senior Manager, Controlling)

It is impossible to describe people's work in a document. It just makes so much sense for us to make sure that the people actually doing the work are also part of defining how to do it. Especially because the business partners and controllers have to work close together, we have to be sure that we are aligned. It actually also differs a bit how well they should be aligned all depending on the size of the sites they are supporting. So it becomes even more important that people talk to each other. (Senior Manager, Business Partnering)

Based on the above, the middle managers did not believe that the interfaces between the two roles could be perfectly defined in a document, as the SLA intended to do. For this reason, they wanted to bring people together physically and have a continuous dia$\log$ about interfaces and where and how to cooperate. To support this process, managers in controlling and business partnering worked together on establishing what they termed "excellence teams" that consisted of controllers and business partners servicing the same areas. These excellence teams met once a month to discuss role interfaces and how they best supported the sites with financial services.

Lateral relations: business partner community Parallel with the process with controlling, the managers in business partnering initiated a business partner community, as production sites were reporting divergent experiences with the business partners, indicating that the role was interpreted and performed very differently. Also, some of the business partners were frustrated about vague instructions for how to carry out their new role. The intention of the community was to help define the role by discussing openly what a good business partner is, but also to lay the groundwork for better evaluating the employees:

We have identified ten measures of what we believe is a good business partner. This will allow us to say 'OK, you are doing fantastic' or 'you got room for improvement, because at the moment, the conversation is around whether someone is supporting the business, well it's quite intangible, and we want to bring more substance into it. (Senior Manager, Business Partnering)

A lot of our business partners used to be finance managers at sites. The new role is very different. They have to step away from the detail and be more overall. Also they cannot be friends with people on the sites, because sometimes we also have to be the 
hard guys. Some people are struggling a lot to make this move. So we have to be really clear about what the role is and how it is different from what a lot of them used to do. So because of this we started the business partner community. (Manager, Business Partnering)

As the business partners were divided into three sub-functions (Fig. 2) serving different parts of the business, the business partner community allowed for a common understanding of the role and how it should be carried out across these different sub-functions.

\section{Structure-people misfit}

A part of the reorganization of FOOD's finance function was a $25 \%$ reduction of full-time employees. In deciding on which employees to lay off, the executive management focused on what they perceived to be critical competencies:

To be able to meet our ambitions and targets, we need really skilled and specialized finance people. We need people that have a lot of experience and are able to work with finance on a strategic level. We don't move the business by focusing on simple book keeping and administration. (Director, Business Partnering)

It's actually quite simple. We wanted to create excellent finance center. A powerhouse you could say. With the very best finance people. (Vice President)

This perception of critical competencies was, however, not shared by middle managers, e.g..... I do not necessarily care if the people working for me are hard-core finance specialists. Of course they have to know the basics, but since they need to work on a more overall level, the most important thing is that they can work their way around in the matrix. You have to be able to build a strong network with the business, prioritize and keep focus...Otherwise you will burn. (Manager, Controlling)

We are a service function. It is important to understand. People need to understand the business we are supporting because they are our customers. When people become too specialized in finance, they forget the customer. You know, too much inside-out. (Manager, Process Optimization)

Related to this, middle managers were reporting a general challenge in making employees fit into the new roles, particularly the finance business partner role:I think that we have underestimated the task of making people perform in the business partner role. Things went really fast in the beginning, so I guess we more or less gave people new titles and overall instructions and moved on to the next thing. Now we are starting to see that a lot of our business partners are not really delivering the role as we intended. I feel like I keep telling the business partners the same thing and they keep making the same mistakes. (Senior Manager, Business Partnering)

Perhaps as a consequence of this misfit, the reorganization brought along issues related to stress, as seen in the example below:I think that we expect a lot of people. We work them really hard. We are still getting the new organization in place, so things can get pretty chaotic at times, because we also have the whole finance machine that needs 
to run. People are working really long hours to make things work and they have been doing that for a long time. Across the whole finance team, we have had quite a lot of cases of stress during the last months which really worries me. (Manager, Business Partnering)

Strategies for engaging with the misfit Working the matrix: "buddy" arrangement Being aware of the need for developing employees' relational skills and "working the matrix," managers within business partnering initiated a buddy arrangement in which experienced business partners who did not hold a management position and knew how to work the matrix were paired with specialists who had to develop into business partners. The more experienced business partner then served as a mentor:

...I need to be really close to my people to make sure that they fill their role out. I have a really busy schedule, so I can't be all over my people all the time. So I came up with this idea with a buddy agreement. It is basically a junior and a senior helping each other in the daily work without involving me. (Manager, Business Partnering)

The buddies engaged in job shadowing, following each other for a day of work once a month and providing feedback to each other. This buddy arrangement was quickly adopted by other middle managers in the other functions within finance, e.g.:My colleague started this buddy arrangement. At first I thought it was really silly. People should just go do their job. I think we work on too high a level for buddies. But my colleague was really doing well with this arrangement, so I tried it out. My people did not really buy into it in the beginning. I must admit that I was surprised in a good way. I guess it helped people feel less alone and feel more confident when battling the business. (Senior Manager, Business Partnering)

Although facing initial resistance, the buddy arrangement proved to be an effective way to reduce the structure-people misfit. Through this, middle managers facilitated the development of employees' competencies toward what they perceived as critical competencies for operationalizing top management's intent.

Working the matrix: safe haven To help employees cope with the high level of pressure in the new organization, managers created different settings where frustration or confusion could be freely expressed. An illustrative example of this was creating a "safe haven":

Because we have so many stakeholders, we have a busy job, that I am using a lot of effort on making sure that my team meetings are a safe haven, if that makes sense... So whenever we are together, it is also a place for them to say 'sorry guys, I really do not understand this' and to ask all the stupid questions, and it gives so much energy in the room when somebody says 'have you seen that mail from HR, I simply do not understand it.' (Senior Manager, Business Partnering)

Obviously I have for each team member a monthly one-to-one, using the vast amount of time speaking about how it is going, and all of the work relating tasks 
we can take outside or ongoing. Also to move a little bit closer to them. Because yes, we have been under a lot of pressure and still are, and you really need to be honest to your manager, to yourself, because otherwise it will hit you sooner or later. (Manager, Controlling)

Keeping the strong performance culture in mind, managers in finance had not previously been concerned with how employees coped with their job. With increasing challenges of stress and employees leaving the company, creating a safe haven emerged as a fruitful way of supporting employees to navigate in the new organization.

Working the matrix: sharing best practice As has been established previously, several misfits were caused by increased uncertainty due to lack of knowledge. The roles and procedures were new which led to confusion and frustration for employees and managers, because no one knew how they should be carried out in the daily work. Middle managers found that the best way to cope with this issue was to fill in the blanks themselves and learn from colleagues' experiences. Examples of this appeared at both employee and management level, as illustrated below:

My people take turn presenting a case from their daily work when we have team meetings. The role is still new and it is fine that there is a group working on a common definition. But I am more concerned with practice. So I like us to share examples of concrete, business partner work. We try to share both good and bad examples. (Senior Manager, Business Partnering)

This is my first management position...I sometimes feel very confused about managing this reorganization. It is definitely much more challenging than I expected. I have been thinking a lot about how we get the structure and processes in place, but all this people stuff is taking a lot of my attention, and I often do not know what to do. Every other week, I meet with colleagues at the same level as me and we share our experiences from this chaotic process. We are not a formal management team, but it is really nice to have somebody to talk to that you do not have to pretend to be a hero (Manager, Controlling)

\section{Strategy-process misfit}

An important part of the new strategy was to streamline and optimize finance processes at all production sites. To achieve this, all sites needed the same finance system. As FOOD's growth was primarily based on acquisitions, several different finance systems were used, which made finance processes inefficient. With the new strategy, FOOD wanted to introduce the financial system, SAP, throughout the organization. As the process started, however, they soon learned that converting all systems to SAP was a far bigger task than expected. The process of replacing old systems with SAP was relatively quick, but a lot of challenges emerged when the sites started to use the system, revealing different maturity levels for handling the system. As a consequence, finance business partners were struggling to deliver main aspects of their new role: 
My people have to serve on average five sites. A big part of their role is to challenge the local management on how they are doing on key numbers compared to other sites. When the sites are still using different systems, it makes it impossible for us to accurately compare across sites. I am surprised that the management don't spend more resources in getting SAP up and running. (Manager, Business Partnering)

IT is a mess. We are trying to get the entire organization to run on the same system. But. Yes, it is just not an easy task. We are working on it, we are. It is a part of our harmonization and standardization agenda. It is just taking much longer than we thought so we have to be patient and accept that things are not perfect. The business partners are bugging us a lot with this. (Senior Manager, Process Optimization)

As the above implies, a consequence of the delayed IT implementation is a temporary misfit to the other design elements, hereby representing a barrier to achieve the new strategy.

Strategy for engaging with the misfit SAP service check The managers within business partnering learned that production sites were struggling to use the new financial system as intended, making it difficult to compare numbers and benchmark across sites. As they examined the problem more closely, they found out that these issues referred to the same user problems in the system. They therefore developed a new work practice, which they termed "SAP service check":

We identified features that are absolutely necessary that all sites obey to. Then a lot of the other stuff in the system can wait. So we call it a SAP service check because we go out to the sites and check if they can do the ten tasks. If they cannot, we will show them how to do it, so we get the right numbers... When we are doing good with the tasks, then we add more stuff, but I guess it has been a good move to split the task, because the sites were really overwhelmed with SAP rollout, so instead of everything is crap, I would rather have us focus on the things that we can actually do. (Senior Manager, Business Partnering)

\section{Middle managers as designers}

As the preceding sections illustrate, the new organizational design in FOOD was a function of a new strategy. The focus of the study was not to observe the middle manager roles that influenced the strategy itself, but to understand the middle manager role that specifically related to the new organizational design. This relates to what prior research has termed middle manager's downward-facing roles (Floyd and Wooldridge 1997). Below, I illustrate how the downward-facing roles did not sufficiently capture middle managers' design efforts, leading therefore to the identification of lateral interactions as the basis for a new middle manager role, designing.

Table 4 compares the strategies that the middle managers used for engaging with the perceived misfits, which led them to make adjustments in the design, to sources of strategic influence of middle managers that existing theory has already reported. From this, it can be seen that the case did not observe any strategies related to Floyd and Wooldridge's (1997) upward-moving roles (e.g., reporting challenges about the new 
design to the executive management). Rather, as middle managers were experiencing misfits in the new design, they directed their attention downward in the hierarchy, focusing on adapting the design to better realize the new strategy. For instance, with the introduction of the SAP service check, middle managers modified the original system rollout plan to be able to meet the strategic objective of comparing key numbers across different production sites. Similarly, by building the buddy arrangement, middle managers wanted to support the implementation of the new roles in finance by sharing knowledge and facilitating learning and thus help people to fill out the role faster.

Interestingly, as Table 4 shows, the analysis also revealed a new role, designing, that has not been sufficiently recognized in prior research. Exemplified by middle managers' establishment of the business partner community and excellence teams, designing refers to how middle managers elaborate on the macro design by building extra coordination mechanisms that are necessary to implement the new macro design and strategy. The designing role relies on middle managers' lateral interaction rather than vertical interactions. Unlike the implementation role identified by Floyd and Wooldridge (1997), designing does not translate top management's intent into action. Rather, designing is a creative and iterative process in which middle managers build micro-level organizational elements needed to realize the intent behind top management's strategy and make the macro structural elements work. This way, the findings show how the downward-facing roles already described in literature did not sufficiently capture middle managers' design efforts, leading to the identification of lateral interactions in which middle managers built structures at micro level.

Comparing strategies outlined in Table 4, most of the strategies that the middle managers applied (working across the lines, establishing lateral relations, building mechanisms for sharing best practice) are all aspects that the overall design of an organization should account for (Galbraith 2014). This case showed that when challenges occurred at micro level due to core design elements that were not defined at macro level, they were developed dynamically at micro level. This way, the case study also illustrated an example of a macro design that was highly dependent of micro adaptions to make it work, hereby highlighting the importance of both macro and micro perspectives in organizational design.

\section{Discussion and conclusion}

Organizations are increasingly moving away from traditional hierarchical structures to more modular forms (Schilling and Steensma 2001). Power and responsibility is decentralized, leading to a de-layering of the hierarchy and greater level of self-management. This study has highlighted the crucial role that middle managers played in implementing a new macro design by building micro-level structures to support the macro design. It has shown that middle managers are not just recipients of organizational design or obstacles that can hinder implementation, but take an active role in designing the system below them and ensuring coordination across the hierarchy.

Drawing on previous research, these findings are not surprising, as interaction and adaption of new structures is expected to integrate the new design in daily work (Balogun and Johnson 2004; Ahearne et al. 2014). What is, however, surprising is the way in which middle managers interacted with the new design. Instead of reporting issues with the new design upward in the hierarchy, middle managers worked across the hierarchy with colleagues at the same level. This way, the findings also support 
previous studies that have examined coordination mechanisms and structures across the hierarchy (Dobrajska et al. 2015; Ahearne et al. 2014).

Designing extends our existing knowledge of middle managers' strategic influence, as it relies on lateral rather than vertical interactions. Additionally, it moves beyond middle managers as design implementers and describes middle managers as actively designing micro dimensions of a macro design. As the study showed, the strategic relevance of the designing role was the ability to build coordination and collaboration that responded to the perceived misfits in the new organizational design (e.g., failure to respond to the demands of the line of business). The implication is the need for rethinking the middle manager role. With the emergence of de-layered organizational forms, middle managers will play a crucial role in binding these complex organizations together and coordinating self-management across the hierarchy. As this study shows, this calls for a new middle manager role, designing, which places the middle manager at the center of organizational design processes.

Relating the above to Gulati and Puranam's (2009) notion of compensatory fit, the present study showed how a powerful informal organization, represented by middle management, compensated for an insufficient formal organization. The middle managers created a strong infrastructure at the micro level that was able to realize the top management's strategic intentions. In line with Gulati and Puranam (2009), this misalignment between the formal and informal organization positively impacted organizational performance, as the initiatives by middle managers advanced the reorganization. However, as Gulati and Puranam (2009) stress, compensatory fit is particularly efficient when the gains from ambidexterity are substantial; it is questionable whether the misalignment would prove fruitful in the long term for FOOD. The new strategy focused on efficiency, and thus the compensatory fit in FOOD seems to be more a symptom of different perceptions of the new design at top and middle managerial levels rather than a pursuit of ambidextrous strategy.

The case did not find feedback loops upward in the hierarchy from middle managers to top managers. While this approach may have led to increased flexibility, there is also the risk that the two management layers become too detached. Previous research (e.g., Ahearne et al. 2014) has demonstrated that the benefits of middle managers' involvement in strategy implementation through flexibility only last up to a certain threshold. After this threshold, problems associated with lack of strategic control outweigh the benefits of flexibility. As this study is based on data collected from one time period in the reorganization, it does not tell us about the long-term consequences of lack of vertical coordination. This could be a relevant focus of future research.

The analysis focused on the different perceptions of the design among executive management and middle management. Executive management perceived the new design as a functional organization, and thus they did not design coordination mechanisms for a matrix (how middle managers perceived the design). In this sense, middle managers developed a micro design to fit their perception of the design, which required more complex coordination as depicted in Fig. 2. As the findings illustrate, the micro design developed by middle managers constituted both structures and processes to ensure sufficient coordination and collaboration across the hierarchy to ensure that tasks were solved.

According to the information processing view, misfits between information processing demand and capacity leave the organization with two options: either it can decrease its need for processing information (e.g., lowering quality), or it can increase 
its capacity for processing information (Galbraith 1974). As FOOD's strategy was very clear on efficiency targets, middle managers were (unconsciously) adopting the latter option, which is illustrated in the following example:

I have this picture in my mind that we have done the easy stuff of the reorganization. The strategy and structure is more or less in place, and now we need to make sure that the rest come along. It is a process...I feel like we are getting better every day. At least on a weekly basis, I run into issues that have not been accounted for (in the new organization). So then I have to come up with a solution. Typically there is no time for involving the executives, so I talk to my colleagues. It is not something formal and fancy, but we make it work. (Senior Manager, Process Optimization)

Based on the above, middle managers ended up compensating for insufficient information processing capacity in the new design. When they were faced with misfits between the new design and organizational reality, they had to come up with solutions to make things work. They designed both processes and structures (e.g., excellence teams). This could also be an explanation of the many cases of stress within finance. When individuals function as increased information processing capacity, they have to be able to handle more complex information and insecurity, which can lead to increased feelings of pressure (Burton et al. 2011). This way, this study also contributes to literature on information processing, by describing how middle managers built extra information processing capacity in the macro design developed by top management.

Another interesting finding from the study is that, at first glance, the case appeared to be a classic hierarchy with a traditional top-down approach to design. But a deeper look into the role of middle managers in the reorganization showed that the design process was much more dynamic, since middle managers were shaping micro dimensions of the design (processes and structures). In this way, the new macro design served as an overall framework for the organization's infrastructure, under which more dynamic approaches to design could emerge. Interestingly, however, this dynamic approach to the design process was not intended. The executive management thought they had developed a complete design for the new finance organization. There were no formal incentives for middle managers to design micro mechanisms. Incentives that the executive management designed for middle managers were based on their contribution to the finance function's strategy must-wins. But as middle managers experienced misfits in the new design, the new designing role thus emerged as middle managers' autonomous and voluntary, yet necessary, behavior.

Although unintended, we can learn from this design approach in which some parts of the design are designed at the top, while leaving other things open to be designed at the micro level. This also entails implications for future research, as the organizational level may not be the most appropriate unit of analysis for studying emerging organizational forms and dynamic approaches to organizational design. As this study has shown, examples of dynamic design are also found at the division or functional level in large organizations. As some of the popular examples of "modern" organizations have now reorganized into classical hierarchies (e.g., Burton et al. 2017), we may see more examples of organizations adopting parts of new forms of organizing or designing some parts (e.g., divisions) of the organization in a more dynamic fashion than other parts (Bernstein et al. 2016). 
As this study is based on a single case, there are limitations related to the generalizability of the findings. Therefore, further research is needed in this area in order to further our understanding of middle managers' role in organizational design and thus what designing at middle management level means. Furthermore, the study is based on data collected 6 months into the reorganization. While the findings show how middle managers built micro dimensions of the new macro design in order to make it work, it would be interesting to see whether these initiatives lasted over time. This highlights the need for future research on if, and how, micro-level adaptions are incorporated in the formal macro design over time.

It should be noted that this paper has not focused on the influence of culture in middle managers' adaption of the new design. Therefore, it could be argued whether some of the middle managers' initiatives, e.g., a "safe haven" in which employees and managers can express insecurity and vulnerability, are culturally shaped. Therefore, future research is needed to illuminate whether these processes occur in other cultural contexts.

\section{Implications for practice}

Similar to the findings of Balogun and Johnson (2004), the present study showed that the absence of extensive up-front design left middle managers with decisions on how the new design was to work in practice, and keeping "business as usual" concurrently may inflict too much stress on the organization. A reorganization sequence in which the new design elements are put in place gradually could resolve this issue, but would also imply a risk of not meeting the strategic targets the reorganization was set out to achieve.

The important role that middle managers play in organizational design needs more attention. In particular, practitioner literature tends to assume that top managers can direct change and thus make reorganizations happen (Balogun 2003). Although acknowledging top management's important role as a part of any reorganization, this study has illustrated the central role that middle managers play in building micro-level organizational elements needed to realize the intent behind the top management's strategy and make the macro design work. In this way, the study also questions whether it is even possible, or desirable, for top management to develop an exhaustive design that applies to the entire organization, particularly in the more geographically dispersed and modulated organizations we are increasingly seeing.

As the case shows, overcoming the pitfalls in the new organization, such as the perceived misfits, required (1) proactive middle manager action that moved beyond simply implementing the design, to co-designing it and (2) vertical coordination and cooperation to ensure efficiency in the implementation process and harvesting from each other's best experiences. As mentioned earlier, the resulting dynamic design process developed naturally rather than intentionally. Luckily, the middle managers skillfully and constructively made the new design work, but it is easy to imagine a case where middle management would resist similar conditions. Management of future reorganization processes could benefit from making explicit which parts of the design are designed by top management and which parts should be designed at a micro level.

The above calls for designing as a core middle manager competence in modern organizations. If middle managers are to play a central role in facilitating coordination and self-management in the future, they may have to spend less time on the "traditional" 
middle manager roles (implementing, facilitating, synthesizing, and championing) and more time building microstructures. This also implies rethinking management training and development programs that typically focus on leadership, change management, motivation, coaching, etc. Training programs could benefit from establishing a common language for organizational design at all managerial levels and teaching middle managers how to design their part of the organization.

\section{Appendix 1}

Table 5 Different perceptions of the new design

\begin{tabular}{|c|c|c|c|}
\hline $\begin{array}{l}\text { Design } \\
\text { element }\end{array}$ & $\begin{array}{l}\text { Executive management team } \\
\text { (vice president and directors) }\end{array}$ & $\begin{array}{l}\text { Middle managers (senior managers } \\
\text { and managers) }\end{array}$ & $\begin{array}{l}\text { Congruence in perceptions } \\
\text { (executive management vs. } \\
\text { middle management) }\end{array}$ \\
\hline \multirow[t]{8}{*}{ Strategy } & Must-wins: & Must-wins: & \multirow[t]{8}{*}{ Yes } \\
\hline & - Valued finance partner & - Valued finance partner & \\
\hline & $\begin{array}{l}\text { - Strong finance } \\
\text { fundamentals }\end{array}$ & - Strong finance fundamentals & \\
\hline & $\begin{array}{l}\cdot \text { Boost standardization } \\
\text { and harmonization agenda }\end{array}$ & $\begin{array}{l}\text { - Boost standardization and } \\
\text { harmonization agenda }\end{array}$ & \\
\hline & - ONE finance team & - ONE finance team & \\
\hline & $\begin{array}{l}\text { • Proactive collaboration } \\
\text { with stakeholders }\end{array}$ & $\begin{array}{l}\text { - Proactive collaboration with } \\
\text { stakeholders }\end{array}$ & \\
\hline & $\begin{array}{l}\cdot \text { Engaged, developed, } \\
\text { and mobile colleagues }\end{array}$ & $\begin{array}{l}\text { - Engaged, developed, and mobile } \\
\text { colleagues }\end{array}$ & \\
\hline & $\begin{array}{l}\text { - Developed and utilized } \\
\text { new technologies }\end{array}$ & $\begin{array}{l}\text { - Developed and utilized new } \\
\text { technologies }\end{array}$ & \\
\hline \multirow[t]{3}{*}{ Structure } & Simple functional structure & Full-blown matrix & \multirow[t]{3}{*}{ No } \\
\hline & \multirow[t]{2}{*}{ Clear roles and command } & Blurred lines & \\
\hline & & $\begin{array}{l}\text { Confusing roles, especially business } \\
\text { partners and controllers }\end{array}$ & \\
\hline \multirow[t]{3}{*}{ Processes } & $\begin{array}{l}\text { Business plan (e.g., } \\
\text { standardization of systems, } \\
\text { SAP) }\end{array}$ & $\begin{array}{l}\text { Few formal processes_-people do } \\
\text { their own thing }\end{array}$ & \multirow[t]{3}{*}{ Partly } \\
\hline & \multirow[t]{2}{*}{$\begin{array}{l}\text { Service-level agreement } \\
\text { (SLA) as a foundation for } \\
\text { collaboration with sites }\end{array}$} & $\begin{array}{l}\text { Service-level agreement (SLA) looks } \\
\text { good on paper but does not reflect } \\
\text { reality }\end{array}$ & \\
\hline & & $\begin{array}{l}\text { SAP is not working on production } \\
\text { sites }\end{array}$ & \\
\hline \multirow[t]{3}{*}{ Rewards } & \multirow{3}{*}{$\begin{array}{l}\text { Rewards given based on } \\
\text { contribution to finance } \\
\text { function }\end{array}$} & $\begin{array}{l}\text { Formal rewards based on finance } \\
\text { function }\end{array}$ & \multirow[t]{3}{*}{ No } \\
\hline & & $\begin{array}{l}\text { Rewards given based on the } 7 \\
\text { must-wins in the strategy }\end{array}$ & \\
\hline & & $\begin{array}{l}\text { Informal rewards based on line of } \\
\text { business }\end{array}$ & \\
\hline \multirow[t]{3}{*}{ People } & $\begin{array}{l}\text { Highly skilled and specialized } \\
\text { finance people }\end{array}$ & $\begin{array}{l}\text { Need for people who can "work the } \\
\text { matrix," e.g. serve both the function } \\
\text { and the business }\end{array}$ & \multirow[t]{3}{*}{ No } \\
\hline & $\begin{array}{l}\text { Need for people that think } \\
\text { more strategic }\end{array}$ & $\begin{array}{l}\text { Difficult to make employees fill out } \\
\text { role as finance business partner }\end{array}$ & \\
\hline & $\begin{array}{l}\text { Frustration—people do not } \\
\text { deliver }\end{array}$ & Concerns about stress & \\
\hline
\end{tabular}




\section{Appendix 2}

\section{Interview guide}

Strategy

- Could you please account for the main elements in the new 2020 strategy that have led to this reorganization?

- How is it implemented?

\section{Structure and role}

- Please illustrate how you see your organization formally. How does it look informally?

- Describe your role. What would a typical day be like?

- What is the most complex or challenging about your job?

\section{Decisions \& processes}

- What kind of decisions do you make, i.e. what can you directly influence, and what needs to be approved above you?

- What kind of decisions have you delegated to your employees?

- What are the key work processes in the daily work?

- How do you work with implementing the new strategy? And the new organization?

\section{Goals \& rewards}

- What are the success criteria for your role? How have these success criteria been set?

- How do these success criteria influence your daily work?

- How do you measure performance?

- What can make it difficult for you to succeed?

- Which success criteria have been set for the people reporting to you?

\section{People}

- What kind of professional and personal competencies do you think are necessary for the new finance organization? Are they different than before?

- What is, in your perspective, the most important focus of the employees / managers working below you in supporting the reorganization?

\section{Perception of the new design}

- What are the main advantages in the new finance organization?

- What kind of challenges do you see in the new design (roles, incentives, goals)? Which of these are perceived / expected and which have you already experienced?

- How do you cope with these challenges? 
- Describe the reorganization - what went well, and what could be improved? How far are you in the process?

- Following the reorganization, you have been put in charge of your own "organization" within finance. Please describe how you have organized your team and why.

- If you had magical powers and could change one thing that would make your work in the reorganization easier, what would that be?

\section{Appendix 3}

Table 6 Summarized code structure

\begin{tabular}{|c|c|c|c|}
\hline Empirical Codes & $\begin{array}{l}\text { Aggregated Empirical } \\
\text { Categories }\end{array}$ & $\begin{array}{l}\text { Conceptual } \\
\text { Themes }\end{array}$ & $\begin{array}{l}\text { Theoretical } \\
\text { Dimensions }\end{array}$ \\
\hline $\begin{array}{l}\text { Chaos, long, confusion, secrets, } \\
\text { fast, unions, political, take-over }\end{array}$ & Reorganization process & \multirow{5}{*}{$\begin{array}{l}\text { Strategy } \\
\text { Structure } \\
\text { Processes } \\
\text { Rewards } \\
\text { People }\end{array}$} & \multirow[t]{5}{*}{ Misfits } \\
\hline $\begin{array}{l}\text { Simple, clear command, functional, } \\
\text { contradiction, matrix, complex, } \\
\text { dotted lines, incomplete, tension, } \\
\text { standardization, logic, no surprises, } \\
\text { half-done }\end{array}$ & The new design & & \\
\hline $\begin{array}{l}\text { Strategic, traditional, performance, } \\
\text { self-reliance, business partner, } \\
\text { controller, tough, service-level } \\
\text { agreement }\end{array}$ & $\begin{array}{l}\text { Professional roles and } \\
\text { expertise }\end{array}$ & & \\
\hline $\begin{array}{l}\text { Value to the business, stress, } \\
\text { pressure, streamline processes, } \\
\text { one customer, employee turnover, } \\
\text { layoff }\end{array}$ & $\begin{array}{l}\text { Impact of new } \\
\text { organization }\end{array}$ & & \\
\hline $\begin{array}{l}\text { Delegation, toughen up, long hours, } \\
\text { trust, micro-manage, rewards, } \\
\text { motivation, filter, protect }\end{array}$ & Leadership & & \\
\hline $\begin{array}{l}\text { Excellence team, business partner } \\
\text { community, safe haven, buddies, } \\
\text { service check }\end{array}$ & New initiatives & Adapting design & $\begin{array}{l}\text { Strategic influence } \\
\text { of middle managers }\end{array}$ \\
\hline
\end{tabular}

\section{Acknowledgements}

I would like to thank managers and employees in the case company for their participation and for letting me be a part of a very difficult period in the company. Also, I would like to thank Børge Obel and Anne Bøllingtoft for their insight and support in writing this paper.

Author's contributions

The author read and approved the final manuscript

\section{Competing interests}

The author declares that she has no competing interests.

\section{Publisher's Note}

Springer Nature remains neutral with regard to jurisdictional claims in published maps and institutional affiliations.

Received: 25 July 2018 Accepted: 5 March 2019

Published online: 30 March 2019

\section{References}

Ahearne M, Lam SK, Kraus F (2014) Performance impact of middle managers' adaptive strategy implementation: the role of social capital. Strateg Manag J 35(1):68-87

Avital M, Te'eni D (2009) From generative fit to generative capacity: exploring an emerging dimension of information systems design and task performance. Inf Syst J 19(4):345-367 
Balogun J (2003) From blaming the middle to harnessing its potential: creating change intermediaries. Br J Manag 14(1):69-83

Balogun J, Johnson G (2004) Organizational restructuring and middle manager sensemaking. Acad Manag J 47(4): 523-549

Bernstein E, Bunch JB, Canner N, Lee M (2016) Beyond the holacracy hype. The overwrought claims_-and actual promise—of the next generation of self-managed teams. Harvard Business Review 94(7-8 (July-August 2016)::38-49

Boland RJ, Collopy F, Lyytinen K, Yoo Y (2008) Managing as designing: lessons for organization leaders from the design practice of frank O. Gehry. Des Issues 24(1):10-25

Braun V, Clarke V (2006) Using thematic analysis in psychology. Qual Res Psychol 3(2):77-101

Burton RM, Håkonsson DD, Nickerson J, Puranam P, Workiewicz M, Zenger T (2017) GitHub: exploring the space between boss-less and hierarchical forms of organizing. J Organ Design 6(1):10

Burton RM, Lauridsen J, Obel B (2002) Return on assets loss from situational and contingency misfits. Manag Sci 48(11):1461-1485

Burton RM, Obel B, DeSanctis G (2011) Organizational design: a step-by-step approach, 2nd edn. Cambridge University Press, Cambridge

Cameron K, Freeman S, Mishra A (1991) Best practices in white-collar downsizing: managing contradictions. Executive 5(3):57-73

Cascio W (1993) Downsizing: what do we know? What have we learned? Executive 7(1):95-104

Chandler A (1962) Strategy and structure: chapters in the history of the American industrial enterprise. MIT Press, Cambridge

Dobrajska M, Billinger S, Karim S (2015) Delegation within hierarchies: how information processing and knowledge characteristics influence the allocation of formal and real decision authority. Organ Sci 26(3):687-704

Donaldson L (2001) The contingency theory of organizations. Sage Publications, Thousand Oaks

Doty DH, Glick WH, Hubber GP (1993) Fit, equifinality, and organizational effectiveness: a test of two configurational theories. Acad Manag J 36(6):1196-1250

Dutton JE, Jackson SE (1987) Categorizing strategic issues: links to organization action. Acad Manag Rev 12:76-90

Eisenhardt KM (1989) Building theories from case study research. Acad Manag Rev 14(4):532-550

Eisenhardt KM, Graebner ME, Sonenshein S (2016) Grand challenges and inductive methods: rigor without rigor mortis. Acad Manag J 59:1113-1123

Fjeldstad ØD, Snow CC, Miles RE, Lettl C (2012) The architecture of collaboration. Strateg Manag J 33:734-750

Floyd SW, Lane PJ (2000) Strategizing throughout the organization: managing role conflict in strategic renewal. Acad Manag Rev 25(1):154-177

Floyd SW, Wooldridge B (1992) Middle management involvement in strategy and its association with strategic type: a research note. Strateg Manag J 13:153-167

Floyd SW, Wooldridge B (1997) Middle management's strategic influence and organizational performance. J Manag Stud 34(3):465-485

Galbraith JR (1974) Organization design: an information processing view. Interfaces 4(3):28-37

Galbraith JR (2014) Designing organizations: strategy, structure, and process at the business unit and enterprise levels. JosseyBass, San Francisco

Gioia DA, Corley KG, Hamilton AL (2013) Seeking qualitative rigor in inductive research: notes on the Gioia methodology. Organ Res Methods 16(1):15-31

Greenwood R, Miller D (2010) Tackling design anew: getting back to the heart of organizational theory. Acad Manag Perspect 24(4):78-88

Gulati R, Puranam P (2009) Renewal through reorganization: the value of inconsistencies between formal and informal organization. Organ Sci 20(2):422-440

Huy QN (2001) In praise of middle managers. Harv Bus Rev 79(8):72-79

Huy QN (2002) Emotional balancing of organizational continuity and radical change: the contribution of middle managers. Adm Sci Q 47(1):31-69

Langley A (1999) Strategies for theorizing from process data. Acad Manag Rev 24:691-710

Liedtka J (2014) Perspective: linking design thinking with innovation outcomes through cognitive bias reduction. J Prod Innov Manag 32(6):925-938

Martin JA, Eisenhardt KM (2010) Rewiring: creating cross-business unit collaborations in multi-business organizations. Acad Manag J 53(2):265-301

Meyer A, Tsui A, Hinings C (1993) Configurational approaches to organizational analysis. Acad Manag J 36(6):1175-1195

Miles RE, Snow CC (1978) Organizational strategy, structure, and process. McGraw-Hill, New York

Milgrom P, Roberts J (1995) Complementarities and fit: strategy, structure and organizational change in manufacturing. J Account Econ 19(2/3):179-208

Nadler DA, Tushman ML (1999) The organization of the future: strategic imperatives and core competencies for the 21st century. Organ Dyn 28(1):45-60

Nickerson JA, Zenger TR (2002) Being efficiently fickle: a dynamic theory of organizational choice. Organ Sci 13(5):547-566

Nissen M (2014) Organization design for dynamic fit: a review and projection. J Organ Design 3(2):30-42

Puranam P (2012) The future for the science of organization design. J Organ Design 1(1):18-19

Puranam P (2018) The micro structure of organizations. Oxford University Press, Oxford

Sayles L (1993) The working leader. The Free Press, New York

Scarbrough H, Burrell G (1996) The axeman cometh: the changing role and knowledge of middle managers. In: Clegg S, Palmer $\mathrm{G}$ (eds) The politics of management knowledge. Sage, Thousand Oaks

Schilling MA, Steensma HK (2001) The use of modular organizational forms: an industry-level analysis. Acad Manag J 44(6):1149-1168

Siggelkow N (2001) Change in the presence of fit: the raise and fall, and the renaissance of Liz Claiborne. Acad Manag J 44(4):838-857

Smith WK, Besharov ML (2017) Bowing before dual gods: how structured flexibility sustains organizational hybridity. Adm Sci Q 64(1):1-44 
Thomas R, Dunkerley D (1999) Careering downwards? Middle managers' experiences in the downsized organization. Br J Manag 10(2):157-169

Van Aken JE (2005) Management research as a design science: articulating the research products of mode 2 knowledge production in management. Br J Manag 16(1):19-36

Van de Ven AH, Ganco M, Hinings CR (2013) Returning to the frontier of contingency theory of organizational and institutional designs. Acad Manag Ann 7(1):393-440

Weick KE (2004) Rethinking organizational design. In: Boland RJ, Collopy F (eds) Managing as designing. Stanford University Press, pp 36-53

Whittington AM, Pettigrew R (2003) Complementarities thinking. In: Pettigrew R, Whittington AM, Ruigrok W, Sanchez-Runde C, Van den Bosch F (eds) Innovative forms of organizing. Sage Publications, London

Yin RK (2014) Case study research: design and methods, 5th edn. Sage Publications, Los Angeles

Submit your manuscript to a SpringerOpen ${ }^{\circ}$ journal and benefit from:

- Convenient online submission

- Rigorous peer review

- Open access: articles freely available online

High visibility within the field

- Retaining the copyright to your article

Submit your next manuscript at $\boldsymbol{\nabla}$ springeropen.com 